rocket is $19 \mathrm{~m}$ long and has an initial weight of 18.4 tons. The first stage, called Emeraude, is a liquid-fuel rocket which burns for $93 \mathrm{sec}$ and has a thrust of 30 tons. The second stage (Topaze) is a solid-fuel rocket giving a thrust of 15 tons for $44 \mathrm{sec}$. The third stage, which burns for 45 sec, is also a solid-propellent rocket. The $A$-1 satellite itself, which has a mass of about $40 \mathrm{~kg}$, did not carry any scientific experiments. But it did have a radio transmitter operating on $136.53 \mathrm{Mc} / \mathrm{s}$; these radio signals ceased after a short time in orbit. The satellite, which received tho international designation $1965-96 \mathrm{~A}$, entered an orbit with the following parameters: inclination to the equator, $34 \cdot 2^{\circ}$; orbital period, $108.5 \mathrm{~min}$; perigee height, $530 \mathrm{~km}$; apogee hoight, $1,800 \mathrm{~km}$; cccentricity, 0.084 . The predicted lifetime in orbit is about 100 years. Ten days later another French satellite, $F R-1 A$, was launched by the United States National Aeronautics and Space Administration, under an international agreement similar to that for the British satellites, Ariel 1 and 2. The $F R \cdot 1 A$ satellite weighs $61 \mathrm{~kg}$ and has been designated 1965-101 $A$. The main experiment, designed by the Centre National d'Etudes des Telecommunications, is concerned with the propagation of very low-frequency radio waves. A second experiment, provided by the University of Birmingham, consists of a probe to measure electron density. The $F R-1 A$ satellite is in a near-circular orbit at a height of about $750 \mathrm{~km}$, the inclination to the equator being $75 \cdot 8^{\circ}$.

\section{Ministry of Technology: Regional Organization}

IN answor to a further question on December 7 , the Minister of Technology, Mr. F. Cousins, said that he had established a strong regional organization, one of the main tasks of which was to promote the more vigorous application by industry of now scientific and technical knowledge resulting from research financed or sponsored by the Government. It was examining the limitation of the supply of information from the research associations to supporting firms and also the method by which information was disseminated through the Ministry's establishmonts. The establishment of the Ministry's regional offices was almost complete: new offices were opened during October in Birmingham, Bristol, Iseeds, Manchester and Nottingham, and a further office for South-East England and East Anglia would be opened early next year. By the end of 1967, the Ministry would have set up a network of about seventy liaison centres, co-ordinating the activities of industry, education and the Governmont, and the regional officers would be represented on the regional planning bodies. At the end of June, the National Research Development Council had 95 development projects in hand; 17 new projects had sinee becn authorized and a further 120 were being asscssed. The Ministry's commitments on development projects exceeded $£ 8$ million.

\section{Metric Screw Threads}

Is an answer in the House of Commons on December 7, the Minister of Technology, Mr. F. Cousins, stated that the International Organization for Standardization had reached agreement on recommendations for generalpurpose scrow threads comprising a system of metric threads and another of inch thrcads, which was the sume as the existing Unified threads. These two systems had been published as British Standards B.S. 3643 and B.S.1580. Three general-purpose screw thread systems were used in Britain to-day, namoly, Whitworth, B.S.F. and B.A. They were littlo used outside Britain, and to perpetuate their use would be to increase the costs of, and hamper, British export trade. The British Standards Institution had recently issued an important policy statement urging British industry to adopt the International Organization for Standardization metric system wherever possible in future designs. 'The statemont had received strong support from industry, and the decision to recommend the use of motric screw threads had the full support of the Minister, although, with the British Standards Institution, he rocognized that certain sectors of industry might find it necessary to continue to use the Unified Inch system for some time. The Institution's statement implied that the Whitworth, B.S.F. and B.A. threads were now to be regarded as obsolescent, although their replacement would be gradual and supplies of screws and tools to the obsolescont standards would be maintained for many years, for servicing designs and equipment already installed. He also supported the Institution's view that these systems should be superseded by metric threads in preference to an intermediate change to the standard inch threads. More than 80 per cent of the population of the world was in countries which had adopted or were adopting the metric system, and British trade with these countries was expanding faster than that with countries not using the metric system.

\section{National Computing Centre}

AGAIN, in a statement to the House of Commons on Decomber 7, Mr. F. Cousins said that a National Computing Centre was to be established. This should reduce wasteful duplication of programming by providing users of computers with information about programmes already available in its library and elsewhere. The Centre would also develop and sponsor the development of programmes designed to serve users having elosely similar tasks. It would provide and oncourage training in systems analysis, programming principles and applications of computers. It would promote research into methods of programming and operating computers and into the influence of these mothods on the design of computers. These objectives would be pursued in close co-operation with the manufacturers of computers and with users in industry, commerce, administration, science and technology. The Centre would be established as an independent non-profitmaking company, limited by guarantee. Mr. Cousins said ho would be inviting representatives of manufacturers, users and of professional and other bodies to become members of the Centre and to serve on its Council. Prof. Gordon Black was being released by the Atomic Energy Authority to become the first director of the Centre, but he would retain his appointment as part-time professor of automatic data processing at the University of Manchester. Mr. Cousins hoped that the Centre would be built in Manchester on a site close to the University, and that it would be fully in operation by 1967 . The Centre would probably require a staff of between 40 and 50, who would not be Civil Servants and would need to be experts. It was intended that the Centre should have a computer.

\section{Dublin Institute for Advanced Studies}

I'He Dublin Institute for Advanced Studies recently celebrated its silver jubilee. Established in 1940 by $\Lambda$ ct of the Irish Parliament, its aims, as laid down in the Act, are the furtherance of advanced study and the conduct of research in specialized branches of knowledge and the publication of the results of such study and resoarch. These aims are carried out through its constituent schools, two of which, the School of Celtic Studies and the School of Theorotical Physics, were establishod in November 1940 and are specifically mentioned in the Act. A third School - the School of Cosmic Physics-was established in 1947. The School of Celtic Studies is now universally recognized as the foremost centre for research in all branches of that subjoct. The School of Theoretical Physics has had on its staff such ominent physicists as Dr. Erwin Schroedinger and Dr. Walter Heitler, and now has, as senior profossors, Dr. J. L. Synge and Dr. Cornelius Lanezos. The first senior professors in the School of Cosmic Physies were the late Prof. L. W. Pollak, Dr. H. A. Brück (now Astronomer Royal for Scotland) and Dr. Lajos Janossy (now at Buda- 